\title{
The state of this World Heritage region as a starting point for regional monitoring
}

\author{
Judith Gasser \& Urs Wiesmann
}

\section{Abstract}

The UNESCO listing as World Heritage Site confirms the outstanding qualities of the high-mountain region around the Great Aletsch Glacier. The region of the World Heritage Site now faces the responsibility to make these qualities visible and to preserve them for future generations. Consequently the qualities of the site must not be regarded in isolation but in the context of the entire region with its dynamics and developments.

Regional monitoring is the observation and evaluation of temporal changes in target variables. It is thus an obligation towards UNESCO, who demands regular reports about the state of the listed World Heritage assets. It also allows statements about sustainable regional development and can be the basis for early recognition of threats to the outstanding qualities. Monitoring programmes face three major challenges: first, great care must be taken in defining the target qualities to be monitored or the monitoring would remain vague. Secondly, the selection of ideal indicators to describe these qualities is impeded by inadequate data quality and availability, compromises are inevitable. Thirdly, there is always an element of insecurity in the interpretation of the results as to what influences and determines the changes in the target qualities.

The first survey of the monitoring programme confirmed the exceptional qualities of the region and also highlighted problematic issues.

\section{The World Natural Heritage Site}

The almost untouched high-mountain landscape around the Great Aletsch Glacier was listed as a UNESCO World Heritage (WH) Site in December 2001 and in June 2007 an enlarged perimeter was approved. Such recognition accorded by UNESCO confirms the outstanding quality of the area, the spectacular landscape and its exceptional beauty. It also entails a responsibility for the entire region in which the $\mathrm{WH}$ Site is situated, to showcase its outstanding universal values and preserve them for future generations. The values within the actual perimeter cannot be regarded in isolation but have to be considered in a greater regional, sometimes supraregional, context. The entire region has to look after its ecological resources, cultural particularities and economic potential. Profound knowledge of the dynamics of the $\mathrm{WH}$ region is therefore essential for the long-term existence of the WH values.

Figure 1 presents an overview of the WH region, with the perimeter in red, defining the actual WH Site. It clearly shows that the region consists mainly of a pristine high mountain landscape. The 25 associated communes are outlined (in black), comprising several municipalities and economic regions.

\section{Regional monitoring}

The main questions concern the dynamics of the region, see also Table 1:

- How is the physical region changing?

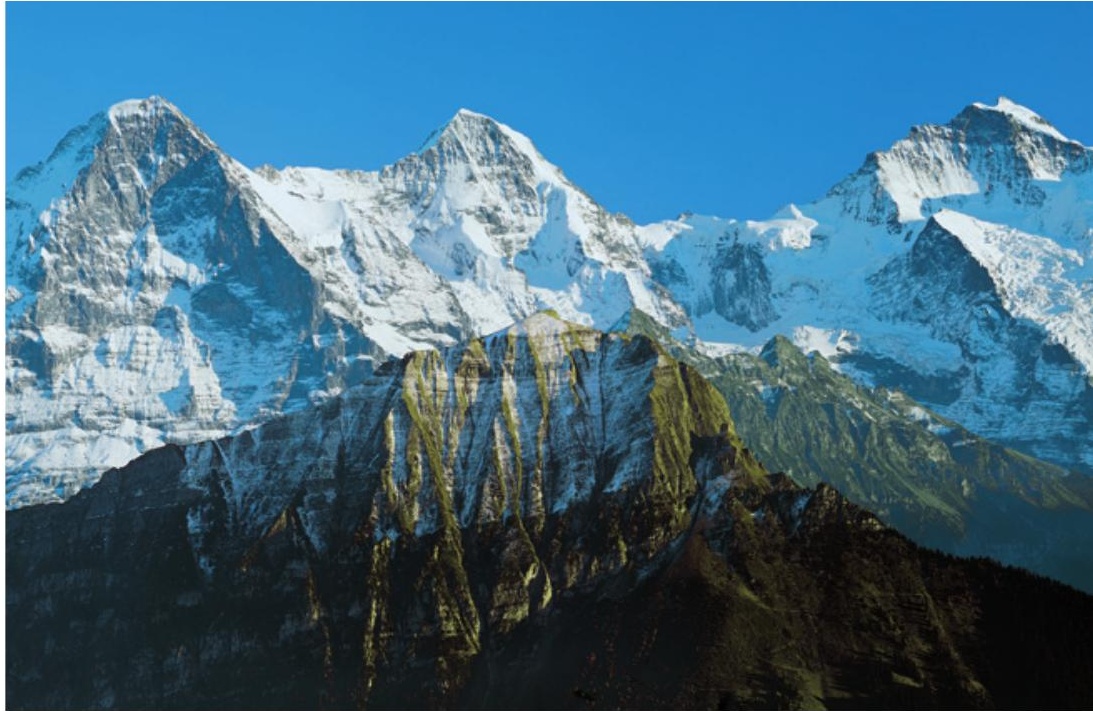

The unique panorama of Eiger, Mönch and Jungfrau. (C) Jungfraubabnen

Table 1 - Monitoring refers to the observation and evaluation of temporal change in target variables (Lass \& Reusswig 2002).

\begin{tabular}{|l|l|}
\hline Observation & $\begin{array}{l}\text { In appropriate observation networks and institutions data are collected as } \\
\text { part of certain indicators. }\end{array}$ \\
\hline Evaluation & $\begin{array}{l}\text { The data are processed so that they can be put in relation to a given } \\
\text { problem. The selection and display of the data is of vital importance in } \\
\text { this context. }\end{array}$ \\
\hline $\begin{array}{l}\text { Temporal } \\
\text { change }\end{array}$ & $\begin{array}{l}\text { Depending on the question to be addressed, it may make sense to have a } \\
\text { different periodicity for survey and evaluation. }\end{array}$ \\
\hline Target variable & $\begin{array}{l}\text { The selection of indicators is essential for a successful monitoring pro- } \\
\text { gramme. It has to match the questions the monitoring is supposed to } \\
\text { answer, thus the accurate and careful formulation of these questions is the } \\
\text { starting point of the monitoring. }\end{array}$ \\
\hline
\end{tabular}




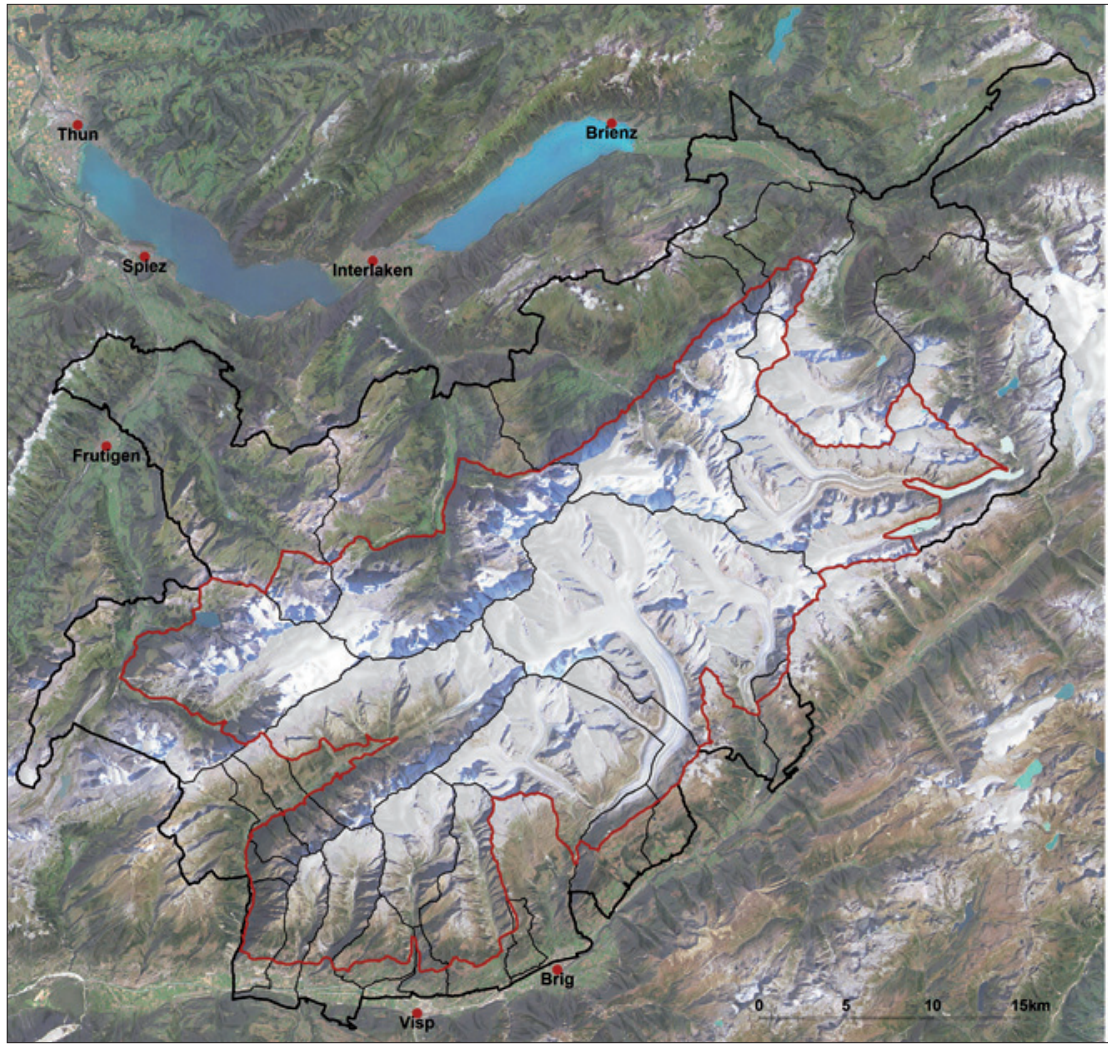

\section{World Heritage Site \\ Swiss Alps \\ Jungfrau-Aletsch}

\section{- Perimeter of the World Heritage Site - Boundary of the World Heritage region - Boundaries of the associated communes - Regional centre}

Figure 1 - Overview of the Swiss Alps Jungfrau-Aletsch World Heritage region on a satellite image of 2005. Satellite image of the WHS Jungrau-Aletsch, BAFU 2009.

- What are the characteristic dynamics of the living environment?

- What economic and structural change is taking place in the region?

Regional monitoring with respect to the Swiss Alps Jungfrau-Aletsch World Natural Heritage Site is an obligation to be fulfilled towards UNESCO, which demands regular reporting about the state of the outstanding universal values of WH Sites (Selfslagh 2004). In addition it provides an opportunity to collect information about sustainable regional development, which is an objective of the management plan for the WH Site (Pound 2004; Wiesmann et al. 2005). Regional monitoring also forms the basis for an early warning system concerning natural hazards or threats and thus for sensitizing the public to specific issues and problems (Fancy et al. 2009). The indicators have to describe the values deduced from the aims of the WH Site management as well as to conform to specific standards (representativeness, sensitivity, availability, etc.) (Manning 2007). Consequently they are derived from the criteria of UNESCO and the aims set out in the management plan (Wiesmann et al. 2005), see Table 2. Based on the

Table 2 - UNESCO criteria for World Heritage listing (World Heritage Convention 2011) and the aims set out in the management plan (Wiesmann et al. 2005).

\begin{tabular}{|c|}
\hline UNESCO criteria for World Heritage listing \\
\hline $\begin{array}{l}\text { Natural sites are outstanding examples representing major stages of Earth's history, including the record of life, significant ongoing geologi- } \\
\text { cal processes in the development of landforms, or significant geomorphic or physiographic features. The Jungfrau-Aletsch region is an exam- } \\
\text { ple of the Alpine orogeny, accommodating a wealth of geomorphic features and the largest coherent glaciated area in the Alps. Ongoing } \\
\text { geomorphic processes, often caused by climate change, can be observed. }\end{array}$ \\
\hline $\begin{array}{l}\text { Natural sites are outstanding examples representing significant ongoing ecological and biological processes in the evolution and develop- } \\
\text { ment of terrestrial, fresh water, coastal and marine ecosystems and communities of plants and animals. The Jungfrau-Aletsch region hosts a } \\
\text { wide variety of alpine and subalpine habitats, in which the ecological succession in particular is exemplary. }\end{array}$ \\
\hline $\begin{array}{l}\text { Natural sites contain superlative natural phenomena or areas of exceptional natural beauty and aesthetic importance. The spectacular land- } \\
\text { scape of the Jungfrau-Aletsch region plays an important role in European literature and art, mountaineering and Alpine tourism. }\end{array}$ \\
\hline Management aims (additional) \\
\hline Natural and cultural landscapes, with their cultural and traditional heritage, are being conserved or developed with respect. \\
\hline $\begin{array}{l}\text { Man, as visitor, stakeholder and cultivator, is welcome in the WHS, as long as he is taking into account the sensibility and vulnerability of } \\
\text { the natural resources. The existing infrastructure is conserved and, if necessary, expanded, always considering the carrying capacity of the } \\
\text { natural balance in the region. }\end{array}$ \\
\hline $\begin{array}{l}\text { The economy is market-orientated and in line with the social and cultural conditions, as well as the legal requirements, and also with the } \\
\text { long-term carrying capacity of the natural environment. }\end{array}$ \\
\hline $\begin{array}{l}\text { The values, uniqueness and beauty of the region are competently conveyed to local people and tourists, in different contexts and at different } \\
\text { levels. The sensitization achieved is motivation for an active debate forming the basis for the long-term preservation of the region's values. }\end{array}$ \\
\hline
\end{tabular}


UNESCO criteria for WH listing and the management aims, seven criteria were determined, linking the WH monitoring to relevant $\mathrm{WH}$ values and management aims (Day 2004). These seven criteria are assessed by the monitoring programme, see Table 3.

\section{The dynamics of the $\mathrm{WH}$ region}

The indicators were each evaluated for the whole region belonging to the Swiss Alps Jungfrau-Aletsch World Natural Heritage Site. The region includes the entire area of the 25 communes with a share of the actual WH Site - there is thus always an inside and an outside of the perimeter. Certain indicators even go beyond that region. There are some indicators for which data are not available for the whole region or not consistently in the same quality. The border between the cantons of Bern and Valais often also marks a boundary regarding certain data content because the two administrations do not always emphasize the same aspects.

\section{Glaciers, climate, water}

The glaciated landscape between the Bernese Oberland and the Rhone valley is the centrepiece of the Swiss Alps Jungfrau-Aletsch World Natural Heritage Site. The monumental glaciers are crucial in accounting for the fascination and uniqueness of the region, and the fact that they are melting away is worrisome to both local people and tourists, scientists or politicians. Therefore glaciers are essential for sensitizing the public to climate change issues. All glaciers within the region have lost in length and volume in recent decades, although at a varying pace (Raetzo et al. 2009).

The effects of climate change can be perceived in the entire area of the WH Site, which is generally characterized by climatic contrasts (North et al. 2007). On the northern side of the Alps, the climate is humid and cool, the inner Alpine valleys of the Valais are drier and warmer. Consequently there are differences in vegetation and thus of agricultural practices. In the Bernese Oberland, water has always been abundant, while in the Valais it is the limiting factor; irrigation has a very long tradition in this area. With the advent of hydro-
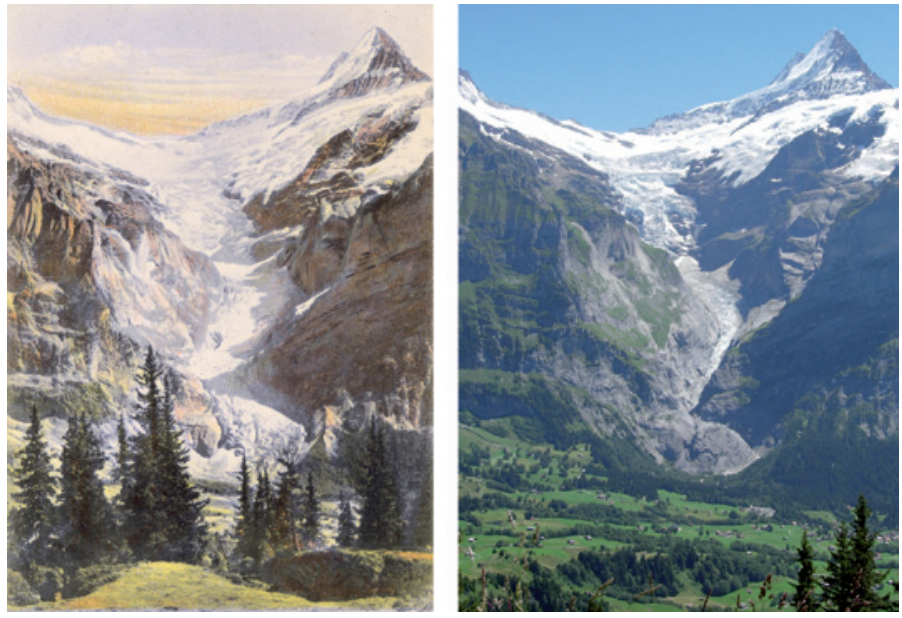

Figure 2 - The Upper Grindelwald Glacier about 1900, compared to a photograph of 2006. Upper Grindelwald Glacier and Schreckhorn about 1900, postcard (photograph), collection HeinzJ. Zumbühl, and 4 August 2006, photograph by Samuel U. Nussbaumer.

electric power plants, the importance of water has risen greatly and now extends far beyond the region itself (Weingartner 2007). The increasing intensification of water use has left its mark on the landscape and has particularly affected the water courses. As a result, they can no longer fulfil important ecological tasks, so that today many rivers are being renaturated (Zeh Weissmann et al. 2009) - Figures 2 and 3.

\section{Morphology, soils, geology}

The alpine landscape is characterized by a number of typical forms and phenomena. Pinched flora, rock and ice dominate the picture. The landscape is subject to certain dynamics due to climate change and it is under pressure from increasing tourism.

Above a certain altitude, the ground is permanently frozen, a phenomenon known as permafrost. Even if its uppermost layer thaws during the warmer months of the year, permafrost is an important factor for slope stability and therefore also for infrastructure safety at high altitudes. Due to global warming, the frozen ground thaws to ever greater depths, and at lower altitudes permafrost sometimes disappears alto-

Table 3 - The seven criteria assessed in the monitoring programme and described by corresponding indicators.

\begin{tabular}{|l|l|}
\hline Criterion & The assessment is based on the following indicators (bold: key indicators for the evaluation): \\
\hline $\begin{array}{l}\text { Outstanding example of earth's } \\
\text { history and climate change }\end{array}$ & $\begin{array}{l}\text { Glaciers (length, expansion), temperature, precipitation, river discharge and regime, permafrost, natural hazards, land } \\
\text { cover }\end{array}$ \\
\hline $\begin{array}{l}\text { Habitats and ecological suc- } \\
\text { cession }\end{array}$ & $\begin{array}{l}\text { Temperature, ecomorphology (physical characteristics of rivers and streams), land cover, landscape fragmentation, } \\
\text { urban sprawl, noise, light emissions, protected areas and inventories, conflicts: conservation vs. use }\end{array}$ \\
\hline Beauty and uniqueness & $\begin{array}{l}\text { Glaciers (length, expansion), ecomorphology (physical characteristics of rivers and streams), permafrost, land cover, } \\
\text { landscape fragmentation, Swiss Heritage communes, aesthetics of the landscape, agricultural land, urban sprawl, } \\
\text { noise, light emissions }\end{array}$ \\
\hline Traditional cultural landscape & $\begin{array}{l}\text { Ecomorphology (physical characteristics of rivers and streams), land cover, aesthetics of the landscape, agricultural } \\
\text { land, corporate structure in agriculture, regionally typical cultivation methods }\end{array}$ \\
\hline Recreational space & $\begin{array}{l}\text { Natural hazards, aesthetics of the landscape, urban sprawl, noise, light emissions, protected areas and inventories, } \\
\text { conflicts: conservation vs. use, population development, infrastructure and supply, tourism }\end{array}$ \\
\hline $\begin{array}{l}\text { Sustainable economic and } \\
\text { living space }\end{array}$ & $\begin{array}{l}\text { Land cover, aesthetics of the landscape, agricultural land, corporate structure in agriculture, urban sprawl, noise, light } \\
\text { emissions, protected areas and inventories, population development, infrastructure and supply, financial power, } \\
\text { commuting flows, employees by sector, tourism }\end{array}$ \\
\hline Identification and sensitization & $\begin{array}{l}\text { Swiss Heritage communes, regionally typical cultivation methods, media presence, art and literature, science, identifi- } \\
\text { cation and contentedness }\end{array}$ \\
\hline
\end{tabular}



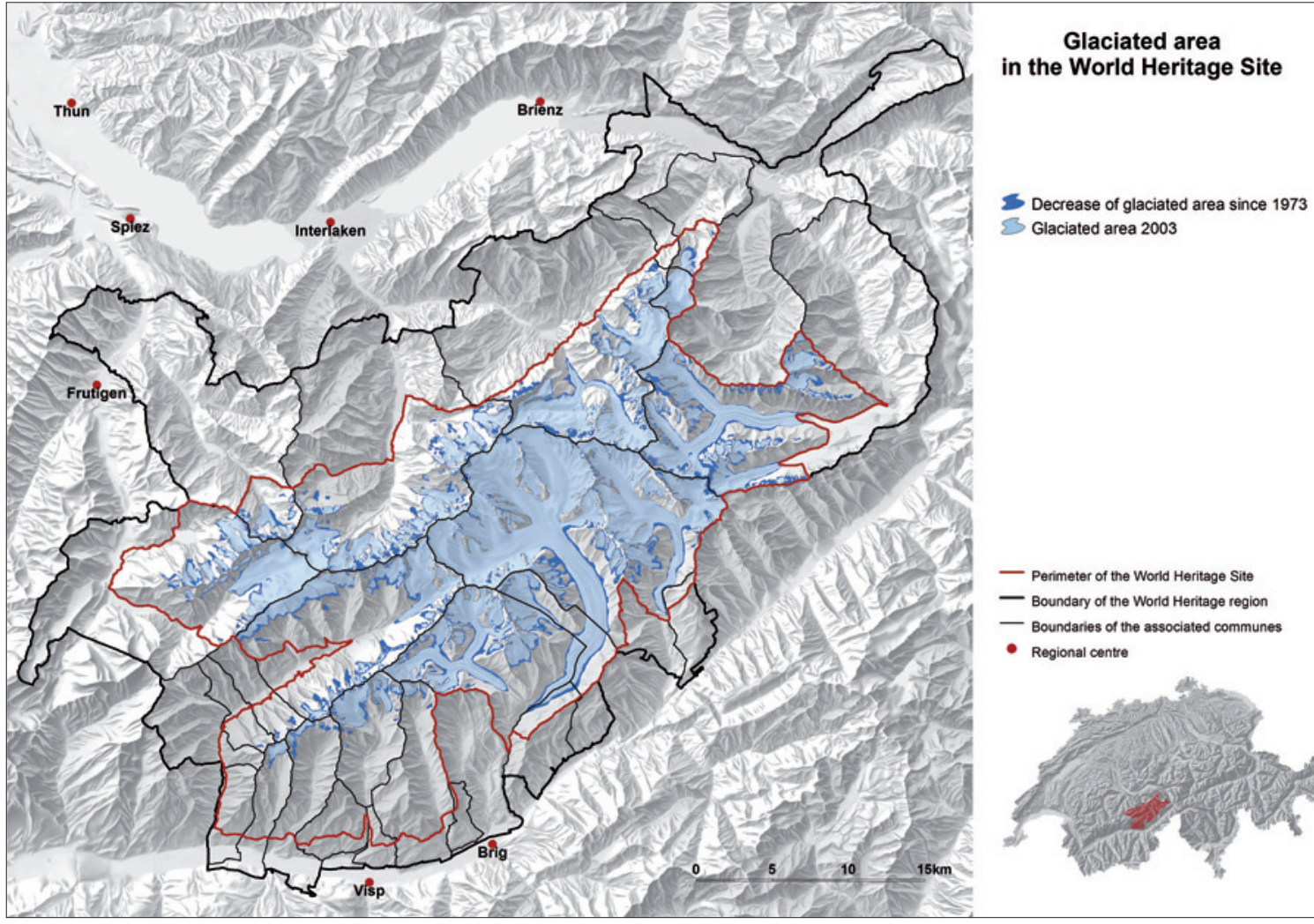

3 Glaciated area 2003

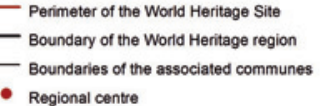

- Regional centre

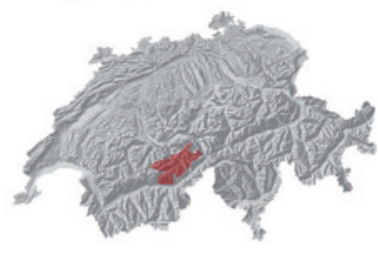

Figure 3 - Changes in the expanse of glaciers from 1973 to 2003. Expanse of glaciers 1973 (Andreas Wipf, Institute for Cartography, ETH Zurich) and 2003 (Frank. Paul, Department of Geography, Zurich).

gether. This has serious implications for natural hazards in mountainous areas. Even though forecasting the future development of the corresponding risks is fraught with uncertainty, in general an increase in both the frequency and the intensity of incidents is expected (Kienholz et al. 2007).

\section{Flora, fauna, habitats}

The wide range of alpine and subalpine habitats is an important feature of the Jungfrau-Aletsch region. The term ecological succession refers to the process of plant populations succeeding each other following natural disturbances like storms or avalanches, and increasingly also due to climate change. The region's characteristic ecological succession is one of the special features distinguishing it as a WH Site (UNESCO criterion 2). Specific climatic and topographic circumstances mark the habitats of all plants and animals. Every landscape hosts niches for specialist flora and fauna and typical biotopes (Küttel 2007). The land cover map (in hectare grid) of the $\mathrm{WH}$ region made available by the Swiss Federal Statistical Office roughly indicates potential habitats and their change (scrub encroachment, glacial recession, etc.). The distribution of many species, particularly fauna, is limited and in some cases threatened by landscape fragmentation: linear traffic infrastructure (roads, railways) dissects and diminishes habitats. Every species, however, needs a habitat of a certain minimum size and for some species even relatively small streets are insurmountable obstacles. Within the perimeter of the WH Site, there are vast, barely fragmented habitats because there is hardly any infrastructure. In large parts of the WH region, the extent of landscape fragmentation is not as great as in the Swiss lowlands. In the peripheral regions around the WH Site, however, fragmentation is on the increase. This is a worrying development, particularly when it affects sensitive and sometimes protected landscapes (Oggier et al. 2001). See Figure 4.

\section{Natural and cultural monuments}

Its outstanding natural beauty is one of the qualities that set the Jungfrau-Aletsch region apart as a UNESCO WH Site. Indeed, the Jungfrau-Aletsch region is globally recognized as one of the most spectacular mountain areas, and its peaks and glaciers are also represented in many works of art and literature. A vital aspect throughout is the close proximity of neat and well-kept cultivated landscapes with rough and untamed high mountains. This contrast is crucial for the fascination and attraction the regions holds.

For the assessment of landscape aesthetics, the entire surroundings that are visible from a certain location are taken into account and valued according to a number of criteria (Roth et al. 2010). No comprehensive study has been conducted yet for the JungfrauAletsch region. As landscape aesthetics are essential in accounting for the uniqueness of the area, they are nevertheless part of the monitoring programme and will be further pursued. 

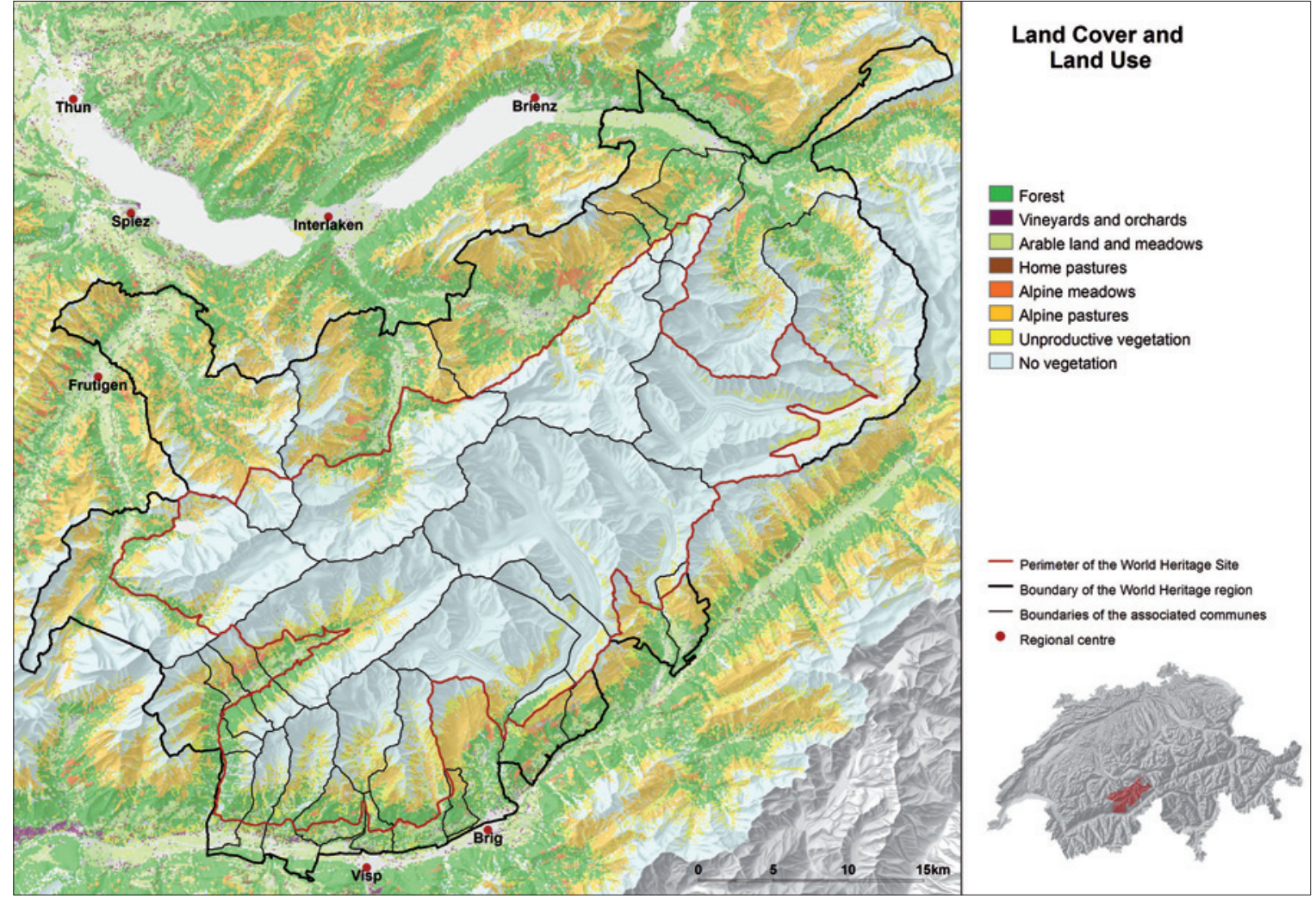

Figure 4 - Land cover in the World Heritage region in eight categories, as a reference point for potential habitats. Land cover: Areal statistics, Swiss Federal Statistical Office 2004.
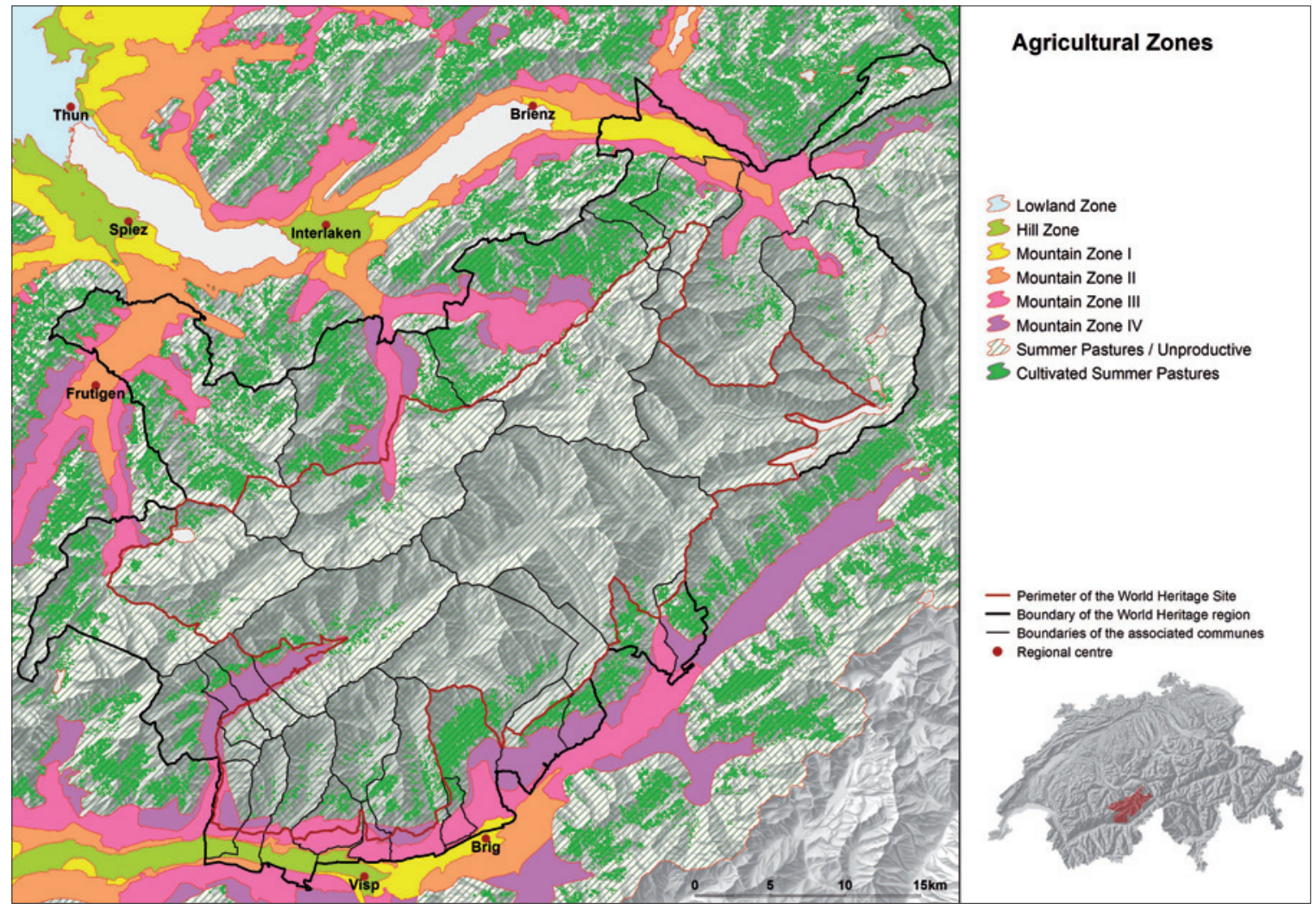

Figure 5 - Agricultural zones with cultivated Alpine pastures. Agricultural zones, Federal Office for Agriculture 2009. 

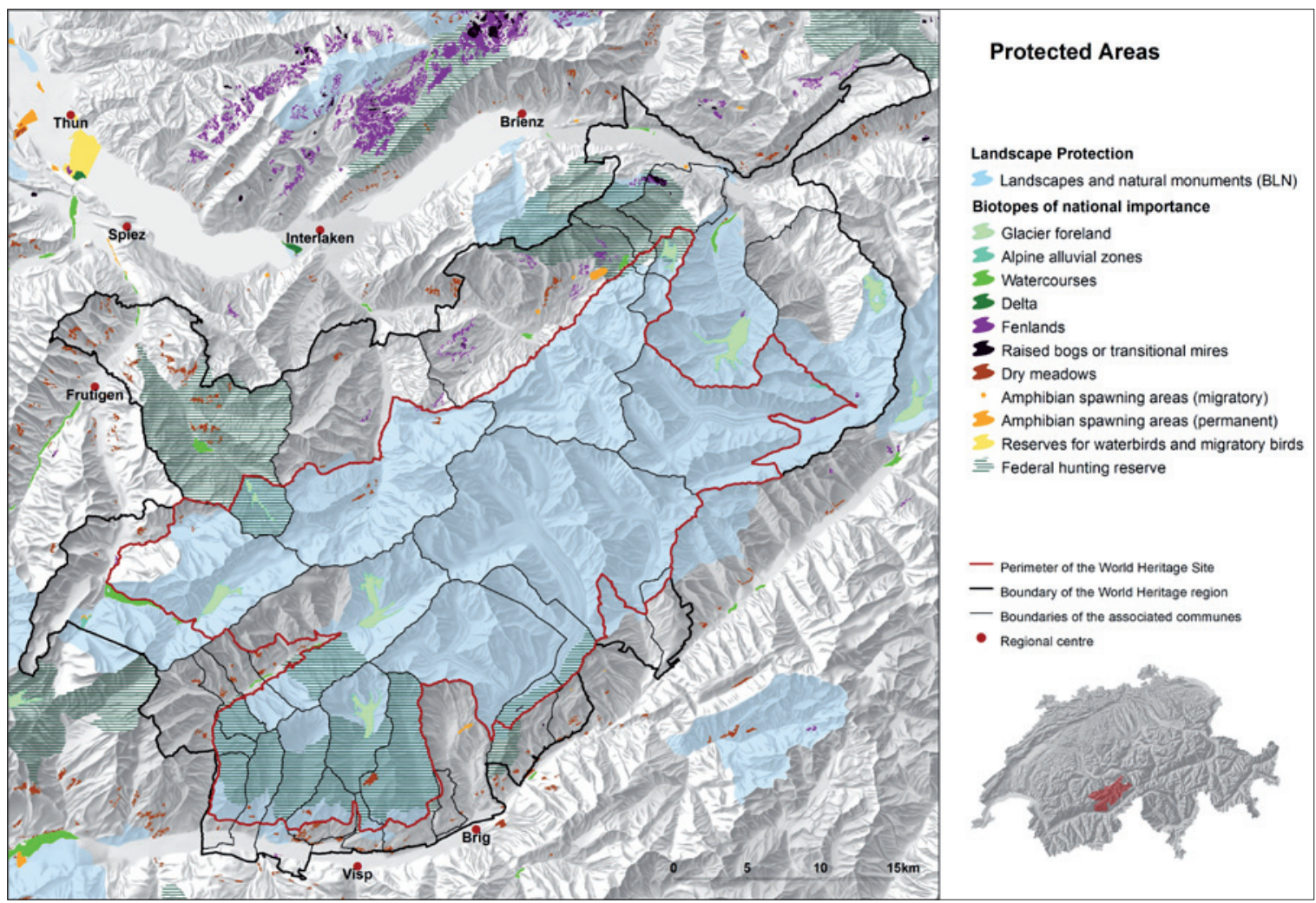

Figure 6 - Overview of the protected areas in the World Heritage region. Protected areas: Swiss Federal Office for the Environment (FOEN); BLN 2008, Water meadows 2007, Mires 2009, Dry meadows 2010, Water bird and Migratory bird reserves 2008, Hunting reserves 2009.

Quality of natural and cultivated landscapes

The landscape of the WH region is significantly shaped by agricultural use. Many beautiful and ecologically important landscape elements, such as dry meadows or mires, would disappear if the respective areas were no longer cultivated. A certain level of agricultural use is essential for the ecological quality of the landscape (BFS 2009), but also for its aesthetic quality, since tourists expect to see a cultivated landscape juxtaposed to the grand natural sights. See Figure 5.

In the Bernese Oberland agriculture is traditionally specialized in livestock farming, with a small number of widely scattered farms and a long-established trade with the lowlands. In the Valais, by contrast, the cultivation of the land is more diverse, due to the drier and warmer climate. Agriculture is traditionally more subsistence-based and the settlements are small and dense, with each farmstead owning some small fields in the surrounding area (Egli 2007).

The quality of the landscape is strongly dependent on the balance between settled/cultivated areas and unspoilt lands - a balance that is threatened by the ongoing urban sprawl (Jaeger et al. 2008). Further factors impacting on the landscape include noise and light emissions at night. While light emissions are still no problem in the region, noise represents a more complex issue. Especially sudden and unpredictable noise, such as that caused by tourist flights, can be a serious disturbance to wildlife (BAFU 2009).
Protection status and spatial development

The vast majority of landscapes that make up the WH Site (more than 95\%) are listed in the Federal Inventory of Landscapes and Natural Monuments of National Importance (BLN), which aims to protect large and cohesive stretches of such landscapes. In addition, the BLN part of the $\mathrm{WH}$ region includes a large number of different protected areas and biotopes. There are water meadows, mires and dry meadows, reserves for water birds and migratory birds, federal hunting reserves as well as cantonal, municipal and private sanctuaries. The listing as WH Site implies no further protective status but represents an obligation for the Swiss authorities to implement the existing regulations and to preserve the outstanding universal values of the site.

There is human use in the entire region; in the core area, tourist activities dominate, mostly outdoor sports. While this use is desired and important for the regional economy, it repeatedly leads to conflicts with the current protection status. One example is the above-mentioned noise from tourist flights. However, individual ski touring or snowshoeing group trips can also disturb hibernating animals (Hammer 2007).

Residential areas, infrastructure, spatial development

The population of Switzerland is growing slightly but there are great regional disparities in population development. While the large agglomerations are ex- 
panding and facing all the problems of urban sprawl, peripheral areas are being vacated. These developments become apparent in the WH region in an exemplary way: places that are easily accessible and close to a regional centre are growing while small and remote places with few employment opportunities beyond the agricultural sector are declining. Traffic infrastructure and the proximity to important services (schools, primary health care, etc.) determine the future of a region. Here, too, there are contrary developments within the WH region: while public transport within and between agglomerations is expanding, the network of post bus routes, connecting peripheral villages to regional centres, is to be reduced. Frequently no young doctors can be found in remote places to take over medical practices, and schools have to be closed because there are not enough children (Goebel \& Ehrensperger 2009; Färber \& Stettler 2006).

\section{Structural and economic parameters}

The term regional economic structure covers the specific economic elements of a place or a region, the labour skills as well as the existing infrastructure. These aspects determine the locational advantage (or disadvantage) of a region. Structural change refers to the change that these aspects are subject to, including the requirements to be met by employees. In most cases the total population benefits from structural change, but regionally and individually it can entail serious disadvantages and painful adjustments (Goebel \& Ehrensperger 2009).

In the monitoring programme, indicators such as commuting flows or the average tax-relevant income give a rough approximation of the economic structure of the WH region. The data clearly point to great economic heterogeneity in the region.

The economic indicators were primarily selected to show the characteristics of different economic sectors in the WH region. It becomes apparent that, especially in this respect, one cannot speak of one region because both economic space and local economic emphases are very diverse. Tourism is the major connecting element; it is important in all WH communes. Some of them, like Grindelwald, are actual tourist destinations and strongly dependent on hospitality trade income. Agriculture is another very significant sector in the entire region. Apart from providing employment, agriculture has a long tradition and shapes a sense of identity among the local population. As mentioned above, cultivated landscapes and agricultural traditions are also an important factor in tourism. Furthermore, biodiversity is only preserved and enhanced by Alpine farming. In most places of the Bernese Oberland, industry is of minor relevance, the only exception being Guttannen and Innertkirchen, where many jobs are linked to the hydroelectric power plant on the Grimsel pass. In the Rhone valley, the industrial sector is stronger; in some larger communes, more people are employed in industry than in the service sector (BFS 2009).

\section{Culture, communication, cooperation}

The last part of the regional monitoring aims to establish how people perceive the WH Site across different aspects. In most cases, the impact of the WH Site cannot be measured easily but has to be determined painstakingly. Nevertheless, it is the goal of the monitoring programme to describe the perception of the region in a comprehensive way. Questions asked to this end include:

- How important are the natural surroundings for the residential population, how content are they with their living environment and how strongly do they identify with it?

- What kind of traditions are there in the region, what do they express and how actively and regularly are they practised?

- How is the WH Site represented in the media and how is this received by the local population?

- Why do tourists visit the WH region, what attracts them?

- How is the fascination for the spectacular mountain region reflected in art and literature and how has this representation changed over time?

- What is the role of the management of the WH Site in the region? What messages are communicated and how are they perceived?

- Which scientific interests are pursued in the WH region, what kind of observational networks are maintained, which scientific problems are studied, which institutions are engaged in the WH region?

All these questions are important for regional monitoring and will be addressed in one of the next steps.

\section{Evaluation and outlook}

Table 4 shows the evaluation based on the indicators employed in the monitoring programme. Each criterion was assigned a value between 1 and 5 :

$5=$ high value in a global context;

$4=$ very high value with regard to the Swiss mountain area;

$3=$ high value with regard to the Swiss mountain area;

$2=$ average value with regard to the Swiss mountain area;

$1=$ low value with regard to the Swiss mountain area;

$0=$ not relevant.

The criteria were each assessed for the areas inside and outside of the perimeter. In a second step, the likely trends of these values were estimated, again for inside and outside the perimeter. This resulted in a first and qualitative evaluation.

It is striking that the WH region achieves high values for many criteria, especially inside the perimeter. But risks were made out as well that threaten some of these attainments. Special emphasis will be put on the quali- 
Table 4 - Evaluation of the World Heritage region based on seven criteria, after analysing the selected indicators. "i.p." stands for "inside perimeter", "o.p." for "outside perimeter". The areas which are under pressure are marked in yellow.

\begin{tabular}{|c|c|c|c|c|c|}
\hline Criterion & i.p. & o.p. & Trend i.p. & Trend o.p. & Remarks \\
\hline $\begin{array}{l}\text { 1. Outstanding example of earth's } \\
\text { history and climate change }\end{array}$ & 5 & 0 & & 0 & $\begin{array}{l}\text { Regardless of people's opinions on the impact of climate change in the region, } \\
\text { the WH Site clearly shows evidence of such change. }\end{array}$ \\
\hline $\begin{array}{l}\text { 2. Habitats and ecological } \\
\text { succession }\end{array}$ & 5 & 3 & & & $\begin{array}{l}\text { Ecological succession and habitats adapt as a result of climate change and shifts } \\
\text { in human use (tourism, agriculture, etc.). To describe these changes, especially on } \\
\text { the scale of single species, more information is required. }\end{array}$ \\
\hline 3. Beauty and uniqueness & 5 & 4 & & & $\begin{array}{l}\text { Inside the perimeter, shrinking glaciers are a threat to the beauty of the region. } \\
\text { Black mountains are generally perceived as less beautiful than white, snowy } \\
\text { mountains. Outside the perimeter, other factors, such as urban sprawl, influence } \\
\text { landscape aesthetics. }\end{array}$ \\
\hline 4. Traditional cultural landscape & 0 & 4 & 0 & & $\begin{array}{l}\text { The differences in agricultural use between the northern and southern parts of the } \\
\text { region are of special interest and value. The continuing abandonment of agricul- } \\
\text { tural land is a major threat to the traditional cultural landscape. }\end{array}$ \\
\hline 5. Recreational space & 5 & 4 & & & $\begin{array}{l}\text { Inside the perimeter, there is an intensification of tourist use, making the high } \\
\text { mountains increasingly accessible to people (heli-skiing, suspension bridges, } \\
\text { cable cars, etc.). This is a threat to the sensitive natural environment. Outside the } \\
\text { perimeter, the devaluation of agricultural land has a direct influence on the quali- } \\
\text { ty of the recreational space. }\end{array}$ \\
\hline $\begin{array}{l}\text { 6. Sustainable economic and } \\
\text { living space }\end{array}$ & 0 & 3 & 0 & & $\begin{array}{l}\text { In comparison with other mountain areas, the WH region has a well developed } \\
\text { economy and is quite easily accessible by public and private transport. Structural } \\
\text { changes (declining importance of the agricultural sector) and the restricted range } \\
\text { of job opportunities (few options for academics) are having a negative impact. }\end{array}$ \\
\hline 7. Identification and sensitisation & 0 & 2 & 0 & & $\begin{array}{l}\text { This aspect is hard to measure. Overall it can be said that there seems to be little } \\
\text { shared sense of identity on the scale of the entire region, and hence no common } \\
\text { identification that would promote the values of the WH Site. }\end{array}$ \\
\hline
\end{tabular}

ties which currently achieve high values but are also under great pressure; see the remarks column of Table 4.

Overall the regional monitoring confirms the outstanding quality of the region. Some aspects of criteria with very high values also face threats and were therefore considered critical. This concerns criteria 3, Beauty and uniqueness, and 5, Recreational space, a little less so criterion 4, Traditional cultural landscape. For criterion 2, Habitats and ecological succession, a negative trend was made out. Further developments will be closely monitored and, if possible, the data available will be increased and improved. Criteria 6, Sustainable economic and living space, and 7, Identification and sensitisation, face opposing trends, while criterion 7 shows the lowest value. It should now be a management objective to enhance this particular area.

Along with the evaluation of various aspects of the WH Site based on the seven criteria went an indirect evaluation of the selected indicators. It became apparent that some indicators are vital for consideration of the criteria while others seem less important or even negligible. In addition, it turned out that the selected indicators enabled comprehensive assessments for some criteria, and sufficient assessments for others, while additional or different indicators are required for a third group of criteria. This is of high relevance for the continuation of the monitoring programme. The selection of indicators has to be reconsidered, possibly adding some and dropping others (Lindenmayer \& Likens 2009).

The following points can thus be made by way of a first conclusion:

- The set of indicators has to be revised and refined on the basis of the evaluation table above.
- The indicators for which there have been no data available so far will be integrated into the monitoring programme as soon as possible.

- Additional information will be sought for those criteria that cannot yet be sufficiently assessed by means of indicators. The same applies to important or extraordinary aspects of a criterion. The relevant dimensions (temporal, spatial, thematic) will be determined on a case-by-case basis.

- If the critical values (particularly Beanty and uniqueness and Recreational space) will have a special status in the monitoring programme, a strategic decision is to be made by the management.

\section{References}

BAFU 2009: Lärmbelastung in der Schweiz: Ergebnisse des nationalen Lärmmonitorings SonBase. Umwelt-Zustand Nr. 0907.

BFS 2009: Betriebszählung 2008. Bundesamt für Statistik, Neuchâtel.

Day, J. 2004. Monitoring and Reporting in Natural World Heritage Areas: A World Heritage Manager's Perspective. In: UNESCO WH Centre and ICCROM (eds.), WH Papers 10: Monitoring WH: 75-82

Egli, H.-R. 2007. Landwirtschaft - Basis der Landschaftspflege. In: Wallner, A., E. Bäschlin, M. Grosjean, T. Labhart, U. Schüpbach \& U. Wiesmann (eds.), Welt der Alpen - Erbe der Welt: 199-220. Bern.

Fancy, S.G., J.E. Gross \& S.L. Carter 2009. Monitoring the condition of antural resources in US national parks. Environmental Monitoring and Assessment 151: 161-174. 
Färber, R. \& D. Stettler 2006. Infrastruktrueinrichtungen und Versorgung im ländlichen Raum. Am Beispiel der Region Jungfrau-Aletsch-Bietschhorn. Diplomarbeit vorgelegt am Geographischen Institut der Universität Bern.

Goebel, V. \& Y. Ehrensperger 2009. Regionale Disparitäten in der Schweiæ. Bundesamt für Statistik, Neuchâtel.

Hammer, T. 2007. Natur- und Landschaftsschutz - Das institutionelle Umfeld. In: Wallner, A., E. Bäschlin, M. Grosjean, T. Labhart, U. Schüpbach \& U. Wiesmann (eds.), Welt der Alpen - Erbe der Welt: 241270. Bern.

Jaeger, J., C. Schwick, R. Bertiller \& F. Kienast 2008. Landschaftszersiedelung Schweiz. - Quantitative Analyse 1935 bis 2002 und Folgerungen für die Raumplanung. Schweizerischer Nationalfonds. Nationales Forschungsprogramm NFP 54: „Nachhaltige Siedlungs- und Infrastrukturentwicklung“. Zürich.

Kienholz, H., F. Schmid, H.R. Keusen \& E. Gertsch 2007. Naturgefahren - Lawinen, Steinschlag, Hochwasser. In: Wallner, A., E. Bäschlin, M. Grosjean, T. Labhart, U. Schüpbach \& U. Wiesmann (eds.), Welt der Alpen - Erbe der Welt: 91-110. Bern.

Koordinationsstelle Biodiversitäts-Monitoring Schweiz 2009. Zustand der Biodiversität in der Schweiz. Ergebnisse des Biodiversitäts-Monitorings Schweiz. (BDM) im Überblick. Stand: Mai 2009. Umwelt-Zustand Nr. 0911.

Küttel, M. 2007. Pflanzen und Tierwelt - Leben unter Extrembedingungen. In: Wallner, A., E. Bäschlin, M. Grosjean, T. Labhart, U. Schüpbach \& U. Wiesmann (eds.), Welt der Alpen - Erbe der Welt: 111-132. Bern.

Lass, W. \& F. Reusswig (eds.) 2002. Social Monitoring: Meaning andMethodsfor an Integrated Management in Biosphere Reserves. Report of an International Workshop. Rome, 2-3 September 2001. Biosphere Reserve Integrated Monitoring (BRIM) Series No. 1. UNESCO, Paris.

Lindenmayer, D. \& G. Likens 2009. Adaptive monitoring: A new paradigm for longterm research and monitoring. Trends in Ecology and Evolution 24 (9): 482-486.

Manning, R.E. 2007. Parks and Carrying Capacity. Washington.

North N., N. Kljun, F. Kasser, J. Heldstab, M. Maibach, J. Reutimann \& M. Guyer 2007. Klimaänderung in der Schweiz: Indikatoren zu Ursachen, Auswirkungen, Massnabmen. Umwelt-Zustand Nr. 0728.

Oggier, P., A. Righetti \& L. Bonnard (eds.) 2001. Zerschneidung von Lebensräumen durch Verkehrsinfrastrukturen COST 341. Schriftenreihe Umwelt Nr. 332.

Pound, Ch., 2004: Monitoring World Heritage Sites. In: UNESCO World Heritage Centre and ICCROM (eds.), World Heritage Papers 10: Monitoring World Heritage: 64-68.

Raetzo, H., A. Bauder, Ch. Marty \& J. Nötzli 2009. Schnee, Gletscher und Permafrost 2007/2008 Neige, glaciers et pergélisol en 2007/2008. In: Swiss Alpine Club (ed.), Die Alpen! - Les Alpes! 9: 52-59.

Roth, U., Ch. Schwick \& F. Spichtig 2010. Zustand der Landschaft in der Schweiz. Zwischenbericht Landschaftsbeobachtung Schweiz (LABES). Umwelt-Zustand Nr. 1010.
Selfslagh, B. 2004. Monitoring World Heritage: A View from the World Heritage Committee's Delegate. In: UNESCO World Heritage Centre and ICCROM (eds.), World Heritage Papers 10: Monitoring World Heritage: $12-16$.

Weingartner, R. 2007. Hydrologie - Im Wasserschloss Europas. In: Wallner, A., E. Bäschlin, M. Grosjean, T. Labhart, U. Schüpbach \& U. Wiesmann (eds.), Welt der Alpen - Erbe der Welt: 73-90. Bern.

Wiesmann, U., A. Wallner, K. Liechti, I. Aerni, U. Schüpbach \& B. Ruppen 2005. Managementplan für das UNESCO Weltnaturerbe Jungfrau-Aletsch-Bietschborn. Naters und Interlaken, Schweiz.

WH Convention 2011. Criteria for UNESCO World Heritage Sites. Available at: http://whc.unesco.org/ en/criteria (accessed 06/09/2011)

Zeh Weissmann, H., Ch. Könitzer \& A. Bertiller 2009. Strukturen der Fliessgewässer in der Schweiz. Zustand von Soble, Ufer und Umland (Ökomorphologie); Ergebnisse der ökomorphologischen Kartierung. Stand: April 2009. Umwelt-Zustand Nr. 0926.

Data for cartography:

CH-Border, lakes, boundaries of communes: GG25 (C) 2008 Federal Office of Topography swisstopo.

Names of communes SWISSNAMES (C) 2004 Federal Office of Topography swisstopo.

Perimeter of the WH Site: Federal Office for the Environment FOEN, 2008.

Relief: PK 100 (C) 1998 and PK 500 (C) 1999 Federal Office of Topography swisstopo.

\section{Authors}

\section{Judith Gasser}

research associate at the Centre for Development and Environment (CDE), University of Bern.

\section{Prof. Dr. Urs Wiesmann}

Director NCCR North-South and Member of the CDE Board. 